\title{
Contingencies of Place and Time: The Significance of Wilson v. Marion and Oklahoma Territory in the History of School Segregation
}

\section{Sara Doolittle}

Between 1889 and 1890, John Wilson and his family were among nearly three thousand African American settlers to enter Oklahoma Territory, where Wilson's two daughters first attended an integrated school. The Wilson family was undoubtedly drawn by the educational and economic opportunities that were present in the fluid space - opportunities that did not always exist elsewhere in the country. Yet the territorial legislature sought to narrow those opportunities, which it did by segregating the schools. Wilson and his family did not accept this limitation and fought back through both the courts and active resistance. This article examines that first legal challenge to the segregated school system: Territory ex rel. Wilson v. Marion et al. This case informs not only our understanding of the durability of racism in an actively contested western space but also the forms of African American resistance to the reactivation of racial bierarchy.

Eva and Janetta Wilson were part of the first class of students at the Fourth Ward School in Guthrie, the capital of the newly formed territory of Oklahoma. The territory was open to non-Native settlement on April 23, 1889, so that first school year was brief. Nevertheless, in the 1890-1891 school year, students moved from barracks tents to fully constructed schools, as the new territorial government established school districts in each of its six counties. Eva and Janetta, ages 8 and 9 , walked a few short blocks from their home to the neighborhood school, where they were taught by Miss Della Seeley in an integrated classroom. It was this kind of education that drew the Wilson family to Oklahoma Territory.

\footnotetext{
Sara Doolittle is a doctoral student in the Educational Leadership and Policy Studies program at the University of Oklahoma. She would like to thank William Frick, Mirelsie Velazquez, Ben Keppel, Megan Benson, and Gregory Stapp for their support as well as the anonymous reviewers and the editors of HEQ for their invaluable help in improving this article.
} 
The Wilsons were African American, and the territory offered them unique conditions - opportunities to own property, federal government oversight, and access to integrated schools. Prior to the Wilsons' arrival in 1890, all-black communities already existed within the Indian Nations. Founded by freedmen of the Five Tribes, these communities had access to the existing network of tribal and missionary schools and extended federal oversight of the Indian Nations. Part of that federal oversight included all-black regiments that patrolled the region as well as additional educational opportunities for soldiers and black residents. When a small section of "Unassigned Lands" in the territory was opened to non-Native settlement in 1889, the Wilsons came for the economic opportunity and had reason to believe that the federally appointed governor and judiciary would extend educational access and afford protections to new African American homesteaders. In that first year, those expectations were borne out: Wilson owned a thriving business - a barbershop in downtown Guthrie - and his two daughters received the best education Guthrie had to offer.

That access changed the following year when the girls tried to reenroll in school. In October 1891, when Eva and Janetta's mother, Belle Wilson, took her two daughters to enroll at the Fourth Ward School, their former teacher, Miss Seeley, turned the girls away. She directed them to the new "colored" school, which was fourteen blocks farther away across Cottonwood Creek and the railroad tracks from the Wilson home. The day after Eva and Janetta were denied access to their home school, their father, John Wilson, approached the city superintendent and was given the same response. Despite this, every morning for the next month, the Wilson girls went to their former school and asked to be admitted. Each morning, they were turned away.

The previous spring of 1891, their county had voted to segregate schools. The Wilsons refused to accept that vote and challenged the county's decision, not only through this active resistance but also in the territorial courts. The territorial attorney general took up their case, which became Territory of Oklahoma ex rel. Wilson v. Francis E. Marion et al., Members of the School Board, and Edward E. Halleck, Superintendent of the Public Schools of the City of Guthrie (1892). ${ }^{1}$ In the title of the case, "Territory ex rel." means the territory would argue

${ }^{1}$ Territory ex rel. Wilson v. Marion et al., Board of School Trustees, District Court of Oklahoma (1892), Supreme Court Case Files, RG 029-01-02, Box 5, Case 44, Oklahoma State Archives, Allen Wright Memorial Library, Oklahoma City, OK (hereafter Supreme Court Case Files). When the school board headed by Francis Marion appealed the original court decision to the Oklahoma Territorial Supreme Court the subsequent case became Marion et al., Board of School Trustees v. Territory ex rel. Wilson, 32 P. 116, 1 Okla. 210 (1893) (Marion v. Territory). 
the case of John Wilson and his daughters against its own school district, challenging segregation. While this may not be an entirely unique occurrence, it was highly unusual and speaks to the complexity of race relations in the territorial space. On May 23, 1892, Judge Edward B. Green handed down his decision in favor of the Wilson family. The victory of the Wilsons in territorial First District Court makes the case a landmark. ${ }^{2}$

The lower court decision in favor of the Wilsons should have meant that the girls would attend their former school, but that lower court ruling was immediately appealed and eventually overturned in the Oklahoma Territorial Supreme Court, where it was renamed Marion v. Territory, and the girls would have to attend a segregated school. The case, among the first heard in the supreme court in the territory of Oklahoma, reveals much about the hopes and aspirations of the territory's African Americans, who dreamed that this western place, with its budding political and social structures, could be different from the rest of the country. The case also reveals their active resistance in the face of attempts to deny those aspirations. By 1890, Oklahoma's territorial schools had already become the primary vehicle to define citizenship-would the dominant white power structure exclude African Americans equal access? The Wilson case helped to determine the answer to that question.

An understanding of Wilson $v$. Marion and the legal and social context that gave rise to it helps to inform us about the role education would play in defining the terms of citizenship for African Americans in this territorial space. Wilson v. Marion immediately challenged the constitutionality of the territory's earliest segregation law, which, in the words of the first territorial governor, was,

${ }^{2}$ Both Gladys Tignor Peterson and J. Morgan Kousser include some of the Oklahoma district and state cases in their compilations of late-nineteenth and early-twentieth-century legal cases combatting segregated schooling. While Kousser does not include Wilson v. Marion, Peterson does. Kousser espouses that only two of the eighty-two cases he chronicles were brought by state attorney generals. Because he does not include Wilson in his figures, I assume it would be the third such case and perhaps the only one brought by a territorial attorney general, of note as the territorial government was largely made by federal appointment. See Gladys Tignor Peterson, "Legal Aspects of Separation of Races in the Public Schools," Journal of Negro Education 4, no. 4 (Oct. 1935), 560-62. Peterson's compendium of early segregation cases details 113 cases between 1865 and 1935, ten of which were in Oklahoma. J. Morgan Kousser, Dead End: The Development of Nineteenth-Century Litigation on Racial Discrimination in Schools (Oxford: Clarendon Press, 1986); and J. Morgan Kousser, "Before Plessy, before Brown: The Development of the Law of Racial Integration in Louisiana and Kansas," in Toward a Usable Past: Liberty Under State Constitutions, ed. Paul Finkelman and Stephen C. Gottlieb (Athens: University of Georgia Press, 2009), 213-70. 
"unconstitutional and will not stand a judicial scrutiny." 3 The case illuminates several larger issues: Due to the inherent fluidity of racial boundaries in the new territory, African Americans held rising expectations for greater social and economic opportunity. To what extent did they prove warranted? What role did schooling play in shaping or limiting those possibilities? The case brings to bear four key themes. First, it reveals the access to land and economic opportunity African Americans had in the territory that was different from their southeastern and even northern counterparts. Second, it provides a view of the distinctive western territorial context that made Oklahoma a pioneering space in which racial lines were less certain, more fluid, and where the racial hierarchy was less rigidly drawn. Third, the case allows for analysis of African Americans' dogged resistance to the reinscription of a racial hierarchy by denying them access to quality education. Finally, it exposes the complexity of the roles whites would play in creating the social, legal, and educational structures of the territory and later the state.

Examining Oklahoma's complex racial and ethnic history has always challenged historians. Its path to statehood was like no other state in the nation. It sits on the border of the East and the Westan "Unassigned Land" the United States government initially designed to provide space for Indigenous as well as relocated western and eastern Indian tribes. These tribes began arriving in the 1830s and 1840s, bringing slaves with them. Later, non-Native settlers would enter the land as homesteaders and settlers, displacing many of those who had come before. In the face of this complex past, historians have often compartmentalized their scholarship, negating a broader understanding of the interplay between these groups. Recently, scholars such as Murray R. Wickett writing on Oklahoma, Quintard Taylor on the broader frontier, and David Chang and Rowan Steineker on the Muskogee-Creek, have examined Oklahoma and the way it informs questions of race and identity in the broader American context. ${ }^{4}$

\footnotetext{
${ }^{3}$ Journal of the First Session of the Legislative Assembly of Oklahoma Territory ... 1890 (Guthrie: Oklahoma News Publishing, 1890), 746.

${ }^{4}$ Murray Wickett's Contested Territory is significant in its approach to the complexity of Oklahoma's history but has only one chapter on education, necessarily divided between tribal, white, and black education. Murray R. Wickett, Contested Territory: Whites, Native Americans and African Americans in Oklaboma, 1865-1907 (Baton Rouge: Louisiana State University Press, 2000). Quintard Taylor details the early legal battles in the West against segregation. See In Search of the Racial Frontier: African Americans in the American West, 1528-1990 (New York: W. W. Norton, 1999). In chapter 7, "The Black Urban West, 1870-1910," he asserts that due to the entrenched "philosophy of racial inferiority" that "few legal challenges were mounted in the nineteenth century" in Oklahoma and Texas. Marion v. Territory and Porter
} 
Meanwhile, in her work on state formation, Nancy Beadie has looked at Oklahoma Territory's legal history in the context of other emerging western territories to help provide a larger analysis of the federal government's oversight and the role education would play in determining the terms of citizenship within frontier America. ${ }^{5}$ Historians from within the state of Oklahoma-Jimmie Lewis Franklin, Arthur Tolson, O. E Hatcher, and Frank E. Balyeat-have a longer history of teasing apart the complicated racial dynamics in this geographical space and the ways in which those dynamics have impacted educational access for African Americans. ${ }^{6}$ The latter two devoted their works to education, with Balyeat chronicling his personal experience

v. Commissioners of Kingfisher County, 6 Okla. 550 (1898) in Oklahoma territory belie that statement. The omissions in his work are perhaps more a testimony to the chaotic nature of record-keeping in the territory and the challenge this presents to archival researchers in accessing these notable cases. Similarly, David Chang provides valuable analysis of the racial dynamics within the state but does so by examining land ownership among the Muskogee-Creek tribe. David A. Chang, The Color of the Land: Race, Nation, and the Politics of Landownership in Oklahoma, 1832-1929 (Chapel Hill: University of North Carolina Press, 2010). Rowan Faye Steineker's work focuses exclusively on Creek education. Rowan Faye Steineker, "Fully Equal to That of Any Children': Experimental Creek Education in the Antebellum Era," History of Education Quarterly 56, no. 2 (May 2016), 273-300.

${ }^{5}$ Nancy Beadie, "War, Education and State Formation: Problems of Territorial and Political Integration in the United States, 1848-1912," Paedagogica Historica 52, nos. 1-2 (Feb. 2016), 58-75.

${ }^{6}$ Scholars O. E. Hatcher, Arthur Tolson, and Frank E. Balyeat provide foundational work on the legal and logistical realities of territorial law and the nature of black education. Ollie Everett Hatcher, "The Development of Legal Controls in Racial Segregation in the Public Schools of Oklahoma 1865-1952" (EdD diss., University of Oklahoma, 1954); Arthur L. Tolson, The Negro in Oklahoma Territory, 1889-1907: A Study in Racial Discrimination (PhD diss., University of Oklahoma, 1966); Arthur Tolson, The Black Oklahomans: A History, 1541-1972 (New Orleans: Edward Printing Company, 1974); and Frank A. Balyeat, "Segregation in the Public Schools of Oklahoma Territory," Chronicles of Oklahoma 31, no. 2, (Summer 1961), 180-92. For broader analysis of the black experience in the territory and state, see Kaye M. Teall, Black History in Oklahoma (Oklahoma City: Oklahoma City Public Schools, 1971). Teall's book was published as a supplementary textbook for students in the Oklahoma City Public Schools. It combines historical overviews of the key topics with primary documents collected by the author; see also Jimmie Lewis Franklin, Journey toward Hope: A History of Blacks in Oklahoma (Norman: University of Oklahoma Press, 1982). Much of the contemporary scholarship about the education of black freedmen and early settlers must be drawn from chapters in larger works about the freedmen of individual tribes. Daniel F. Littlefield Jr., The Chickasaw Freedmen: A People Without a Country (Westport, CT: Greenwood Press, 1980); and Kevin Mulroy, The Seminole Freedmen: A History (Norman: University of Oklahoma Press, 2007). See also Joy McDougal Smith, "Alice Lee Elliott Memorial Academy: A School for Choctaw Freedmen," Chronicles of Oklahoma 72, no. 3 (Fall 1994), 264-79. 
with integrated education in rural parts of the state in the early twentieth century.

This paper uses the case of Wilson $v$. Marion to illuminate the significance of Oklahoma Territory in the larger legal history of school segregation in the United States. Legal historians have documented many of the landmark segregation cases, most notably Brown vs. Board of Education (1954). Simple Justice, by Richard Kluger, provides a comprehensive narrative of the case, its participants, and the NAACP's role in the case that overturned "separate but equal" in American schools. Most works of legal history respond in some way to Kluger's work. Other historians who have reexamined Brown include Mark V. Tushnet, who has written broadly on the laws of slavery, race, and the Constitution. He provides an extensive history of the NAACP and its "litigation campaign model" to desegregate schools, along with strong biographic works of Supreme Court Justice Thurgood Marshall. He has also written on the legacy of Brown. James T. Patterson has also addressed the complex aftermath of Brown. All focus on twentieth-century constitutional history in federal court and the relevance to desegregation in law. ${ }^{7}$

Increasingly, legal historians have turned their attention to segregation cases in the nineteenth century to more closely examine state and local cases. This more dynamic period of legal history prior to the Plessy v. Ferguson (1896) decision helps to inform our understanding of the legal context of the territorial decisions in Oklahoma. These works include Kim Cary Warren writing about Kansas and Mae Ngai writing about the landmark California case Tape v. Hurley (1885). Both works explore notions of citizenship and the shifting dynamics of race in the late $1800 \mathrm{~s} .^{8}$ This was a pivotal period in terms of educational segregation law. Prior to Plessy v. Ferguson, local case law was written with a variety of outcomes for African American children. In examining this time span, roughly from the end of the 1850 s to the 1920 s and 1930s, legal historians have focused on federal-level cases, but less

${ }^{7}$ Richard Kluger, Simple Justice: The History of Brown v. Board of Education and Black America's Struggle for Equality (New York: Knopf, 1975); James T. Patterson, Brown v. Board of Education: A Civil Rights Milestone and Its Troubled Legacy (New York: Oxford University Press, 2001); Mark V. Tushnet, Making Civil Rights Law: Thurgood Marshall and the Supreme Court, 1936-1961 (New York: Oxford University Press, 1993); and Mark Tushnet, The NAACP's Legal Strategy against Segregated Education, 1925-1950 (Chapel Hill: University of North Carolina Press, 2005).

${ }^{8}$ Kim Cary Warren, The Quest for Citizenship: African American and Native American Education in Kansas, 1880-1935 (Chapel Hill: University of North Carolina Press, 2010); and Mae M. Ngai, The Lucky Ones: One Family and the Extraordinary Invention of Chinese America (Boston: Houghton Mifflin Harcourt, 2010). 
work has been done on important state-level decisions. Territorial courts have garnered almost no attention. ${ }^{9}$ The work of Gladys Tignor Peterson and, more recently, J. Morgan Kousser has begun to fill that gap by providing an accounting and analysis of state decisions, many previously unreported. ${ }^{10}$ My work joins other scholars who seek to provide a "bottom-up" view of the law-one that builds on these scholars' work by illuminating the ways in which the early legislative and legal actions on the part of Oklahomans forestalled the efforts of those who sought to legalize an older racial order, one that was threatened by the changeable nature of the more egalitarian western territories. ${ }^{11}$

Beginning with Wilson and his two daughters, dozens of families fought for educational access in Oklahoma, recognizing that education was the battleground on which they would fight for their economic opportunities and civil equality. This work seeks to establish the political, legislative, bureaucratic, and judicial context in which Wilson and his allies in the territorial government struggled as well as the points of resistance to their fight. Wilson $v$. Marion arose out of these cultural conditions to become established law. To begin, we need to understand the distinctive history of the Indian and Oklahoma territories and the origins - unique in character-of the territory's African American population.

\section{Territorial Context}

Oklahoma's most famous writer, Ralph Ellison, in his seminal work Going to the Territory, described Oklahoma as a "magnet for many individuals who had found disappointment in the older area of the country, white as well as black." 12 In the minds of many, the dominant social order based on white superiority and black inferiority was not firmly established in Oklahoma in the early territorial period. Factors present in the territory in the nineteenth century that were not necessarily true

\footnotetext{
${ }^{9}$ See Douglas J. Ficker, "From Roberts to Plessy: Educational Segregation and the 'Separate but Equal' Doctrine," Journal of Negro History 84, no. 4 (Oct. 1999), 30114; and Stephen J. Riegel, "The Persistent Career of Jim Crow: Lower Federal Courts and the 'Separate but Equal' Doctrine, 1865-1896," American Journal of Legal History 28, no.1 (Jan. 1984), 17-40. A notable exception is the work of Peterson and Kousser.

${ }^{10}$ Kousser, Dead End; and Kousser, "Before Plessy, before Brown."

${ }^{11}$ Most influential in my approach is the work of Tomiko Brown-Nagin, Courage to Dissent: Atlanta and the Long History of the Civil Rights Movement (Oxford: Oxford University Press, 2011); and Jacquelyn Dowd Hall, "The Long Civil Rights Movement and the Political Uses of the Past," Journal of American History 91, no. 4 (March 2005), 233-63.

${ }^{12}$ Ralph Ellison, Going to the Territory (New York: Random House, 1986), 132.
} 
for African Americans elsewhere in the country gave them reason to hope. These included access to both educational opportunities and free property ownership, continuing federal oversight and protection, and the relative fluidity of the western context. African American settlement in Oklahoma went through three distinct periods: first was the arrival of African Americans as slaves of the Five Tribes forcibly removed to Indian Territory in the 1830s and 1840s; second, the emancipation and internal migration within the tribal lands as freedmen between 1866 and 1889, following the Civil War and prior to nonNative settlement; and, finally, the arrival of African American soldiers, settlers, and homesteaders, both prior to and in the initial land run of 1889 as well as with subsequent openings of western lands as the territory moved toward statehood.

\section{Pre-Civil War}

The first African Americans to arrive in Indian Territory did so as slaves to the Five Tribes, or as they were known, the Five Civilized Tribes, so named by whites in part due to their practice of slaveholding. Many of these eastern tribes had developed agrarian lifestyles that depended on slave labor and, when faced with removal to Indian Territory, converted many of their assets into human capital. ${ }^{13}$ These slaves marched alongside those tribes - the Creek, Seminole, Choctaw, Cherokee, and Chickasaw-who joined indigenous tribes as well as plains tribes pushed south by white settlement in Kansas and Nebraska. ${ }^{14}$ In this new space, the Five Tribes continued and adapted their own systems of governance, justice, and education; their livelihoods continued to depend on the use of slave labor. ${ }^{15} \mathrm{By}$ $1860,47,550$ Indians were living in Indian Territory along with a small number of whites (4 percent of the population) brought in as agricultural laborers. Slaves made up 14 percent of the population-8,376 black men, women, and children. ${ }^{16}$

During this time, slaves in some tribes had informal occupancy "rights" to their own land, based on occupation and enclosure. Unlike the settled South, Oklahoma Territory offered land and provided a toehold for blacks to have expectations for, and later gain, access to more formal land ownership in the post-Civil War era. ${ }^{17}$

${ }^{13}$ Michael F. Doran, "Negro Slaves of the Five Civilized Tribes," Annals of the Association of American Geographers 68, no. 3 (Sept. 1978), 337.

${ }^{14}$ Wickett, Contested Territory, 4-5.

${ }^{15}$ Doran, "Negro Slaves of the Five Civilized Tribes," 341.

${ }^{16}$ Doran, "Negro Slaves of the Five Civilized Tribes," 347.

${ }^{17}$ Wickett, Contested Territory, 66. 
Federal oversight was also a part of Indian Territory - a strategy the government used to manage the territory during this time and to protect the sovereign Indian nations from white encroachment.

The removed Indian tribes brought with them preexisting education systems, but all developed strong formal structures once in Indian Territory. Coinciding with the rise of the common school movement, a network of schools was built and variously overseen by the tribes and individual denominational missionary organizations. ${ }^{18}$ While Indian tribes saw inherent value in education as a tool to gain political and economic autonomy, they also saw it as a tool to maintain power over the slaves within their nations. Though accounts of integrated schools exist in Indian Territory in the Seminole Nation, the majority of tribes did not allow slaves (or white children) to have an education. ${ }^{19}$ Though African Americans were largely excluded from the educational systems the tribes created, it is significant that these systems existed at all. Increasingly, the burgeoning new scholarship on formal education in antebellum Indian Territory reveals systems of schooling that compare favorably with less systematic school provisions elsewhere in the US, especially the Southeast. ${ }^{20}$ Thus the conditions that existed in Indian Territory in terms of land rights, federal oversight, and educational access created different expectations for some African Americans than for their counterparts in the Southeast and would later become a foundation upon which later rights could be built.

\section{Reconstruction and the Creation of the Twin Territories}

During the Civil War, the Five Tribes sided with the South, in large part due to their slave-dependent economies. After the Civil War, just as the Union required that each state in the Confederacy adopt a new constitution, the tribes were required to "negotiate" new treaties. ${ }^{21}$ The new treaties controversially conferred tribal citizenship rights

${ }^{18}$ Wickett, Contested Territory, 5, 68-78. Additionally, Steineker's work enriches existing notions of Indian education during the nineteenth century. Steineker, "Fully Equal,", 273-300.

${ }^{19}$ Balyeat, "Segregation in the Public Schools," 189. See also Wickett, Contested Territory, 79; and Mulroy, The Seminole Freedmen, 287.

${ }^{20}$ Christina Snyder, "The Rise and Fall and Rise of Civilizations: Indian Intellectual Culture during the Removal Era," Journal of American History 104, no. 2 (Sept. 2017), 386-409; and James D. Anderson, The Education of Blacks in the South, 1860-1935 (Chapel Hill: University of North Carolina Press, 1988), 23.

${ }^{21}$ Donald A. Grinde Jr. and Quintard Taylor, "Red vs Black: Conflict and Accommodation in the Post Civil War Indian Territory, 1865-1907," American Indian Quarterly 8, no. 3 (Summer 1984), 211-29. 
and land rights on newly freed slaves, a situation markedly different from freedmen in the Southeast. ${ }^{22}$ The United States also took advantage of this renegotiation to enforce a punitive reduction in the overall land under tribal control. ${ }^{23}$ This reduction in land split the Indian Territory in two-commonly referred to as the Twin Territoriesan eastern section still called Indian Territory reserved for the Five Tribes, and a western section called Oklahoma Territory that opened the way for the removal of additional plains tribes. Oversight of the western tribes in the newly named Oklahoma Territory was carried out first from Fort Arbuckle and later from Fort Sill, where African American soldiers supervised the dividing line between "civilized" and "wild" Indians. These army posts offered educational opportunities in integrated schools and dormitories for soldiers, their families, and area children. ${ }^{24}$

Like African Americans in the western Oklahoma Territory, the newly freed African Americans in Indian Territory had different opportunities from those in the former Confederate states because as tribal slaves, many were granted informal land rights ${ }^{25}$ What was clearly a period of profound loss for the collective land ownership of tribes became a source of autonomy for the freedmen. Seminole, Creek, and Cherokee tribes allotted land ranging from forty to more than a hundred acres to their former slaves, opening to the freedmen possibilities of farming, raising cattle, governmental representation, town building, and ultimately self-sufficiency through the acquisition of land-based capital. ${ }^{26}$ These opportunities, along with the demand for labor that Indian capitalist developers created, brought an influx of southern blacks, which tripled during this time period and led to the rise of all-black communities in Indian Territory. ${ }^{27}$ The "Black

${ }^{22}$ Treaty with the Cherokee, July 19, 1866, 14 Stat. 799; Treaty with the Creek, June 14, 1866, 14 Stat. 785; Treaty with the Seminole, March 21, 1866, 14 Stat. 755; Treaty with the Choctaw and Chickasaw, April 28, 1866, 14 Stat. 769; Indian Appropriations Act, March 2, 1889, 23 Stat. 894; Curtis Act, June 28, 1898, 30 Stat. 495; and the Atoka Agreement, April 23, 1897.

${ }^{23}$ Beadie, "War, Education and State Formation," 67; and Wickett, Contested Territory, 8-13.

${ }^{24}$ Dixie Smith, interview by Maurice R. Anderson, June 25, 1937, Indian Pioneer History Project, Western History Collections, University of Oklahoma, http://digital.libraries.ou.edu/cdm/ref/collection/indianpp/id/2148; and Evelyn Radcliffe, Out of Darkness: The Story of Allen Allensworth (Menlo Park, CA: Inkling Press, 1995).

${ }^{25}$ Franklin, Journey toward Hope, 10. See also Hannibal B. Johnson, Acres of Aspiration: The All-Black Towns in Oklahoma (Austin, TX: Eakin Press, 2002).

${ }^{26}$ Cheryl Elizabeth Brown Wattley, A Step toward Brown v. Board of Education: Ada Lois Sipuel Fisher and Her Fight to End Segregation (Norman: University of Oklahoma Press, 2014), 6.

${ }^{27}$ Grinde and Taylor, "Red vs Black," 217. 
Exodus" of freed slaves from the South to Kansas and Oklahoma promised land ownership and the opportunity for economic freedom and political equality. 28

Throughout this period, schooling was a primary concern for freedmen living in the Twin Territories. In an October 1866 letter, a federal official reported that "the freedmen, particularly, are anxious that their children shall be educated ... now that they are placed on an equality with their former masters, they are determined to profit by the position." 29 Though formal Reconstruction ended in the South in 1876, the Twin Territories were still under federal oversight, with a federal commissioner appointed to oversee "relations between freedmen of the Indian Territory and their former masters." ${ }^{30}$ Missionary efforts and the existing school systems the tribes developed enriched the freedmen's educational opportunities. The Seminole, Cherokee, Creek, and eventually the Choctaw tribes all provided schools for their freedmen, while the Chickasaw did not, requiring their freedmen to travel to schools in either Indian Territory or Oklahoma Territory or to military installations in the area. ${ }^{31}$ The evolving access to land and education during this time period impacted the expectations of African Americans that this space could be different. These aspirations are apparent in their actions once the territory was opened to nonNative settlement.

\section{Opening of Oklahoma Territory}

Succumbing to pressures by white settlers, some famously known as Boomers, to open parts of the territory to non-Native settlement, in 1889 the federal government released a small area of land in the western part of Indian Territory formerly designated as "Unassigned Lands." These two million acres were opened to settlement by land run in 1889 under authority of the Organic Act of 1890 . This constant pressure from whites for more land led first to the Dawes Act (1887) and later to the Curtis Act (1898), which required that Indian lands be individually allotted and the remaining land within the present

\footnotetext{
${ }^{28}$ Franklin, Journey toward Hope, 11; Robert G. Athearn, In Search of Canaan: Black Migration to Kansas, 1879-80(Lawrence: Regents Press of Kansas, 1978); and Nell Irvin Painter, The Exodusters: Black Migration to Kansas after Reconstruction (New York: Alfred Knopf, 1977).

${ }^{29}$ J. W. Dunn to D. N. Colley, Oct. 1866, quoted in Teall, Black History in Oklahoma, 83.

30 "Circular No. 28" Dec. 6, 1866. Bureau of Refugees, Freedmen and Abandoned Lands, for Arkansas and Indian Territory, Offices of Assistant Commissioner, Little Rock, Arkansas, quoted in Teall, Black History in Oklahoma, 83.

${ }^{31}$ Grinde and Taylor, "Red vs Black," 216.
} 
boundaries of Oklahoma offered up for non-Indian homesteading through a series of land runs, lotteries, and, later, blind auctions. ${ }^{32}$ These opportunities for free land placed no restrictions on race. The land represented hope for African Americans-both those already living there as freedmen and soldiers as well as the approximately three thousand black settlers who came to Oklahoma Territory hoping to establish themselves as truly free and politically empowered. ${ }^{33}$ A contemporary newspaper editorial by Guthrie resident D. J. Wallace promoted Oklahoma as "a fine, free and healthy country ... where every man has equal protection of the law regardless of color. White and colored attend the same schools, and the race prejudice is almost unknown. The best of feelings exists between the two races and I believe it will continue." ${ }^{34}$ Wallace was correct in his assessment. Schools were legally integrated those first years (18891891) throughout the new territory-before the first segregation laws were passed.

Enterprising black boosters drew on these conditions of free land and educational access to actively promote Oklahoma Territory as a land uniquely suitable to the former slave. Many discussed the possibility of Oklahoma becoming an all-black state. Edward P. McCabe was a vigorous promoter of the all-black town of Langston, Oklahoma, which was the site of the only all-black post-secondary educational institution. He and others advocated for President Benjamin Harrison to appoint him territorial governor, and he interviewed with the president in $1890 .{ }^{35}$ Papers from neighboring states and as far away as the New York Times reported on the potential for Oklahoma to become a:

...negro State, in which the white man will only be tolerated because of his business qualifications. The brotherhood [a local African American advocacy group] will fill all State, county, and municipal offices, if their dreams are fulfilled, and they now seem likely to be, and will have only negro school teachers, compelling mixed school attendance, and demand full social equality from such whites as love of money will bring to citizenship. ${ }^{36}$

\footnotetext{
${ }^{32}$ Wickett, Contested Territory, 53-54.

${ }^{33}$ Chang, The Color of the Land, 7.

${ }^{34}$ D. J. Wallace, “A Colored Opinion: What a Newcomer Thinks of the Negro's Chances," Weekly Oklahoma State Capitol (Guthrie, OK), March 28, 1891, 2.

${ }^{35}$ Teall, Black History in Oklahoma, 150; Franklin, Journey toward Hope; Taylor, In Search of the Racial Frontier, Johnson, Acres of Aspiration; Wattley, A Step toward Brown; and Wickett, Contested Territory.

36"To Make a Negro State," New York Times, Feb. 28, 1890, 1.
} 
In part as a result of earlier freedmen settlement patterns, and in addition to the emigration movement that McCabe and others publicized to southern blacks, territorial Oklahoma and Indian Territory saw the growth of a large number of all-black towns that allowed the early settlers to prosper economically. These towns had banks, groceries, attorneys, churches, civic groups, newspapers, and schools. Integrated towns such as Guthrie, Muskogee, Ardmore, and Oklahoma City, where large concentrations of African Americans had settled, had numerous black-operated businesses and schools. ${ }^{37}$ One such business owner was John Wilson, who ran a successful barbershop in thriving downtown Guthrie, the new territorial capital. ${ }^{38}$ Out of these conditions, a professional class of African Americans emerged, including a healthy community of lawyers. The 1910 US Census reported more than sixty black attorneys in Oklahomamore than in any state. ${ }^{39}$

The advocates for black statehood and the large number of black attorneys gave rise to a number of advocacy groups in the state. Many leading attorneys not only founded these groups but ran African American newspapers. ${ }^{40}$ The Oklahoma Negro Protective League, the Constitutional League, and other groups, such as the AntiLynching Bureau and the Union League for Freedom and Justice, reflect the desire to mobilize grassroots support systems for African American legal rights. ${ }^{41}$ In addition to legal rights, the Ida M. Wells Teachers' Association and a similar group in Indian Territory focused on improving educational facilities and the quality of instructional materials for territorial classrooms. ${ }^{42}$

Territorial Oklahoma was a space in which African Americans prospered, gained land ownership, and had full civic and educational participation. The distinctively western context of the territory, with its less rigidly defined racial hierarchy, allowed a strong professional, civic, and educationally minded community of African Americans to develop. These conditions drew families like the Wilsons, who were then joined by reform-minded, federally appointed allies in the territorial government-men like Attorney General Charles Brown and

\footnotetext{
${ }^{37}$ Franklin, Journey toward Hope, 23.
}

${ }^{38}$ James W. Smith, ed., Smith's First Directory of Oklahoma Territory, for the Year Commencing August 1st, 1890 (Guthrie, OK: J. W. Smith, 1890), 328.

${ }^{39}$ R. O. Joe Cassity Jr., "African-American Attorneys on the Oklahoma Frontier," Oklahoma City University Law Review 27, no. 1 (Spring 2002), 250.

${ }^{40}$ Nudie Williams, "The Black Press in Oklahoma: The Formative Years, 18891907," Chronicles of Oklahoma 61, no. 3 (Fall 1983), 308-19.

${ }^{41}$ Cassity, "African-American Attorneys," 260.

${ }^{42}$ Wattley, A Step toward Brown, 8; and Franklin, Journey toward Hope. 
Republican attorney Thomas Howard Soward. However, this confluence of early settlers - white and black - also generated intense racism that would lead to the first battle over segregation in Oklahoma Territory.

\section{Wilson and His Allies}

Wilson, born in Ohio in 1840 to Virginia-born parents, lived in Kansas for many years. It is possible that his parents had traveled the Underground Railroad from Virginia to Ohio, where the first and fourth stops belonged to families named Wilson, the latter a John Wilson. From there, the family joined the migration of Ohio abolitionists to Kansas Territory after the Kansas-Nebraska Act. The Ohio Anti-Slavery Society firmly believed in equal education and in educating blacks with marketable skills. Once in Kansas, Wilson joined fellow Ohioans in the southeast town of Winfield, where T. H. Soward and others would soon build a small college, one that would shortly provide the nascent University of Oklahoma with its first president and half its new faculty. ${ }^{43}$ In Winfield, Wilson established a barbershop in the prominent, white section of town catering to the community's civic elites. He lived above it along with his employee. John and the barbershop prospered, and in the early 1880s he married IsabelleBelle-twenty years younger, who hailed from Michigan. Two daughters and a son followed. ${ }^{44}$

Wilson and his family might have come to Logan County as one of the forty-three African Americans to stake a claim in that first land run. More likely, they were among the 2,973 African Americans who arrived in Oklahoma Territory after the initial 1889 opening. ${ }^{45}$ By 1890, Wilson had a barbershop between First and Division in the bustling downtown of Guthrie and a home where the nicer houses were being built. The girls attended an integrated school nearby. Notably, the Wilsons did not live in the notoriously flood-prone bottomlands of

${ }^{43}$ David W. Levy, The University of Oklahoma, A History, vol. 1, 1890-1917 (Norman: University of Oklahoma Press, 2008).

${ }^{44}$ Basic demographic information on John Wilson and his family was obtained through census records, including the 1880 US Federal Census for Winfield, Kansas; the 1885 Kansas State Census for Winfield, Kansas; the 1900 US Federal Census entry for John Wilson in Ponca City, Oklahoma Territory; and the 1900 US Federal Census entry for Belle Wilson, his wife, in Arkansas City, Kansas.

${ }^{45}$ US Census Bureau Population of Oklaboma and Indian Territory, 1907 (Washington, DC: Government Printing Office, 1907), 8-9. See also Wickett, Contested Territory, 54; Lynne Marie Getz, "Partners in Motion: Gender, Migration, and Reform in Antebellum Ohio and Kansas," Frontiers 27, no. 2 (Jan. 2006), 102-35; and Smith's First Directory of Oklahoma Territory, 328. 
Cottonwood Creek, where many other blacks settled and where the all-black school would be located.

The lawyers who acted on the Wilsons' and the territory's behalf, Brown and Soward, were part of this same early migration into the territory. Like Wilson, Soward had come to Guthrie from Winfield, Kansas. Soward participated in the land run of 1889 and had been named East Guthrie's first mayor. Though he grew up on a plantation with slaveholding parents, Soward served in the Union army during the Civil War. A contributing founder of the Methodist College of Winfield and an elected representative in several local governing bodies, Soward was drawn by the news of Oklahoma's opening and, while still living in Kansas, he served on a committee to plan and design the City of Guthrie. ${ }^{46}$

Brown also came to Guthrie from Kansas, arriving between 1889 and 1890 along with his wife and four children. At thirty-one, he was a young man but became one of only thirteen elected council members (which functioned as the senate) to the first territorial legislative session in 1890. In the waning days of that session, the governor also appointed him as the territory's first attorney general. ${ }^{47}$ Soward and Brown were both reform-minded Republicans closely allied with black Republicans in Guthrie and the area surrounding the city in Logan County.

Wilson, Brown, and Soward had all witnessed the ongoing battle over segregation in Kansas. Their roots in Kansas and the legal precedents established there were an important circumstance in Oklahoma territorial history and the African American migration there. Kansas, like Indian Territory, had long been a destination for escaped slaves and later was a refuge for freedmen and freedwomen. Kansas Territory had been, as early as 1855, a magnet for both the most ardent abolitionists and equally intent slaveholders-both groups battled to determine the course of the state and ultimately the nation: free or slave. The opposing factions remained after statehood and became political parties crafting legislation that would alternately create and deny equal opportunity to the expanding black population. By the time Oklahoma Territory opened the "Unassigned Lands", no fewer than eighteen pieces of legislation and several court cases had imposed the terms of black Kansas citizenship through control of its schools' racial composition. Most notably, in 1876, Kansas joined many northern states in legislating a bold civil rights vision that extended to the state the federal Civil Rights Act passed the year before. It stated,

${ }^{46}$ Walter A. Lybrand, ed., Proceedings of the Twelfth Annual Meeting of the Oklahoma State Bar Association (Oklahoma City: Harlow Publishing, 1919).

${ }^{47}$ Journal of the First Session of the Legislative Assembly of Oklahoma Territory, 1052. 
"District schools ... shall at all times be equally free and accessible to all the children resident therein." Both pieces of legislation responded to the US Supreme Court's disappointingly narrow interpretation of the Fourteenth Amendment's equal protection clause in the Slaughterhouse Cases (1873) and United States v. Cruikshank (1875). The Wilsons, as well as Brown and Soward, had then witnessed the Kansas school equity law fall victim to the amendment process permitting segregation in more populous towns. ${ }^{48}$

The two attorneys had also seen ordinary black families successfully challenge segregation in state court. In the 1881 case Tinnon v. Board of Education, the Kansas Supreme Court found that the Ottawa, Kansas, school board had no authority "to establish separate schools for white and colored children, and to exclude colored children from the schools established for white children for no other reason than that they are colored children." 49 Notably, the Kansas Supreme Court failed to invoke the Fourteenth Amendment's equal protection clause despite it being successfully employed in the stirring lower court decision. The judge presented a more limited interpretation, one that nevertheless found on behalf of young Leslie Tinnon. The school board, he wrote, had no authority to segregate under Kansas law. Brown and Soward undoubtedly took note of this legal precedent as well as the Supreme Court's decision in the Civil Rights Cases (1883) that would limit the protection for black citizens to sue for discrimination. Thus the Wilsons and the lawyers who would take up their case knew intimately that the battleground on which they would fight for full participation for African Americans would be in the classroom and that, in many cases, the way into the classroom would be through the courthouse door. But first, Brown would attempt to shape racially integrated education in the Oklahoma Territory legislature. ${ }^{50}$

${ }^{48}$ Slaughterhouse Cases, 83 U.S. 16 Wall. 36 (1872); United States v. Cruikshank, 92 U. S. 542 (1875); and "Chapter CXXII-Common Schools," State of Kansas: The Session Laws of 1876 (Topeka, KS: Geo. W. Martin, Kansas Publishing House, 1876), 256-57.

${ }^{49}$ Board of Education v. Tinnon, 26 Kan. 1 (1881). Courts had already applied a separate but equal rule for education in Bertonneau v. Board of Directors of City Schools, 3 F. Cas. 294, 296 (C.C.D. La. 1878) (No. 1,361) and would again in U.S. v. Buntin, 10 F. 730 (C.C.S.D. Ohio 1882), but the question had not been heard by the high court. Riegel, "The Persistent Career of Jim Crow," 28. These federal civil rights decisions regarding school segregation left the discretion in the hands of the local authorities under state law. The Tinnon case was a state case.

${ }^{50}$ The Civil Rights Cases, 109 U.S. 3 (1883). For the legal battle for integrated schools in Kansas, see Kansas Session Laws of 1876, 256-57; Board of Education v. Tinnon, 26 Kan. 1 (1881); Warren, The Quest for Citizenship; James C. Carper, "The Popular Ideology of Segregated Schooling: Attitudes toward the Education of Blacks in Kansas, 1854-1900," Kansas History: A Journal of the Central Plains 1 


\section{Debating School Provisions in Oklahoma Territory}

In 1890 during the first territorial legislature, lawmakers set about creating a school system for its citizens, yet the arguments that immediately arose over whether those schools would be segregated or integrated revealed ideological fissures that would prove difficult to resolve. Despite lengthy efforts to find compromise, the legislature ultimately passed that determination on to the then six territorial counties. What became clear through the course of this debate was just how crucial opponents of an integrated society viewed schools and the role they would play in creating the legal terms of citizenship.

The unique qualities of the territorial debate included the very characteristics of its government. Under the terms of territorial government, federal power and politics remained paramount, with the US president appointing key leadership positions. In the early days of Oklahoma Territory, President Harrison appointed a northern Republican as governor and Republicans as its judiciary. The legislature was elected locally, and Republicans also held a slim majority. Democrats, who had largely entered the territory from the South or migrated in from Indian Territory, were in the vocal minority and complained passionately that the required federal oversight was akin to the "carpet bag" era of Reconstruction. Republicans were able to maintain their majority because African Americans were also voting members of the party. The burgeoning populist movement and its third party, the People's Party, further complicated the political scene. As populists increasingly fused with Democrats in Oklahoma Territory, the Republican coalition with African Americans was crucial, though tenuous, to their majority. After a series of black electoral defeats, the Langston City Herald stated, "We apprehend no little uneasiness as to the future confidence the negro can have in Oklahoma Republicans ... We warn you now Mr. Republicans and all others, that the negro is a man, a citizen learned and free, and will not always serve as political booster." ${ }^{51}$ This uneasiness was well founded; eventually most Republicans joined with the Democrats on the issue of

(Winter 1978), 254-65; Kousser, "Before Plessy, before Brown," 213-70; Sondra Van Meeter, "Black Resistance to Segregation in the Wichita Public Schools, 1870-1912," Midwest Quarterly 20, no. 1 (Oct. 1978), 64-77; Randall B. Woods, "Integration, Exclusion, or Segregation: The 'Color Line' in Kansas, 1878-1900," Western Historical Quarterly 14, no. 2 (April 1983), 181-98; Andrew Kull, "A NineteenthCentury Precursor of Brown v. Board of Education: The Trial Court Opinion in the Kansas School Segregation Case of 1881," Chicago-Kent Law Review 68, no. 3 (June 1993), 1199-1206; and Davison M. Douglas, Jim Crow Moves North: The Battle over Northern School Segregation, 1865-1954 (New York: Cambridge University Press, 2005).

${ }^{51}$ Langston (OK) City Herald, Nov. 17, 1892, 1. 
segregation, abandoning their black constituents. In 1890, as the first legislature met in Guthrie, the fluidity of party affiliation continued to contribute to the sense of rising political strength in the black communities, who had at least one black representative, Green Currin, in the new legislature. The embattled Republican Party understood the urgency of garnering this community's votes. ${ }^{52}$

That first year, the legislature assembled in August 1890, under the authority of the Organic Act. High on their legislative agenda was creating a public school system. Councilman Brown introduced Council Bill No. 2, "A Bill establishing a public school system in the Territory of Oklahoma and providing for the maintenance thereof." Before Council Bill No. 2 was out of committee, Democrats, who had a majority on the committee, had amended it to institute territory-wide segregation. ${ }^{53}$ Brown attempted to restore Council Bill No. 2 to its original wording but failed, and the bill stalled on the council floor. Council Resolution No. 7 expressed the urgent situationthe time to build new schools was quickly passing. The resolution urged that they authorize the Secretary of the Interior to allow the larger cities-Guthrie, Kingfisher, and Oklahoma City- to use military barracks to house the children. By October 14, the first compromise bill was heard, one that offered counties a choice: "Various counties of the Territory may each for themselves determine as to whether or not colored or white children shall attend the same or separate schools in their counties." Brown voted no on the bill, pronouncing it "unconstitutional," but he lost and the bill proceeded to the house. The proposed bill now provided for school segregation by county option. ${ }^{54}$

The legislature continued to debate the terms of the county option well into the winter months. Amendments outlined very narrow-and some might argue purposely specific - parameters for county elections and appointing clerks and judges. Should segregation pass, the amended bill provided for "equal school facilities." 55 When the county option bill was heard before the council, Brown called it a "hardship to both white and colored ... it therefore ought not to pass." ${ }^{56} \mathrm{He}$ called it a "delegation of legislative powers" and predicted it would be declared void by the courts, as indeed he would soon

\footnotetext{
${ }^{52}$ Megan Benson, "Reform and Retaliation: Cora Diehl and the Logan County Election of 1891," Oklahoma Politics 4, (Oct. 1995), 25-42.

${ }^{53}$ Journal of the First Session of the Legislative Assembly of Oklahoma Territory, 21; Hatcher, "The Development of Legal Controls," 78.

${ }^{54}$ Journal of the First Session of the Legislative Assembly of Oklahoma Territory, 254.

${ }^{55}$ Journal of the First Session of the Legislative Assembly of Oklahoma Territory, $295,296$.

${ }^{56}$ Journal of the First Session of the Legislative Assembly of Oklahoma Territory, 706.
} 
attempt to do as attorney general on behalf of John Wilson. ${ }^{57}$ Nevertheless, the bill passed the council. The governor, who had opposed the bill, citing the added expense of a dual school system, nevertheless signed it. In his signing statement he observed:

a great deal of difficulty ... on the subject of mixed or separate schools ... I have no doubt, [they] are unconstitutional and will not stand a judicial scrutiny, and only have my consent to stand because I am fully advised that to send this bill back would mean no schools for the children of the Territory for the next several months, hence my approval. ${ }^{58}$

Historians have often misinterpreted this legislation as proof of how entrenched segregation was in the early territory. Instead, examining these minutes reveals that the legislation forestalled immediate stateimposed legislated segregation.

Though the legislative battle was not a victory for those opposed to segregation, Councilman Brown and others still must have hoped that the more progressive Logan County, where black residents made up 30 percent of the voting population, might vote against the segregation option. ${ }^{59}$ According to the compromise legislation, if a county voted to establish separate schools, the Board of County Commissioners had to levy a countywide ad valorem tax for the separate schools. Residents would pay both their local school district taxes and the countywide ad valorem tax based on their property values. That tax had to be sufficient to maintain an equal separate school. ${ }^{60}$ The tax should have been a deterrent to segregation because it penalized taxpayers-in essence, they would be voting to double tax themselves-yet in reality, the dual tax system would never be equal, despite many legal challenges throughout the territorial period and beyond. ${ }^{61}$

Despite hopes and economic interest to the contrary, in April 1891, Logan County School District voted to segregate its schools.

${ }^{57}$ Journal of the First Session of the Legislative Assembly of Oklahoma Territory, 542.

${ }^{58}$ Journal of the First Session of the Legislative Assembly of Oklahoma Territory, 746. See also Hatcher, "The Development of Legal Controls," 78; and Balyeat, "Segregation in the Public Schools."

${ }^{59}$ Benson, "Reform and Retaliation," 28.

${ }^{60}$ Hatcher, "The Development of Legal Controls," 78.

${ }^{61}$ Camille Walsh, Racial Taxation: Schools, Segregation, and Taxpayer Citizenship, 1869-1973 (Chapel Hill: University of North Carolina Press, 2018). Walsh's work provides a much needed and thorough examination of the historical legal challenges to "taxpayer" based funding for schools. See also Will T. Little, L. C. Pittman, and R. J. Barker, The Statutes of Oklahoma, 1890 (Guthrie, OK: State Capitol Printing Company, 1891), Chapter 79, Article XIII, sec. 1-9, 1142-1143, quoted in Hatcher "The Development of Legal Controls," 79. 
The election was chaotic, in large part due to the legislation's overprecise regulations (likely on purpose), but additionally, the territory had also voted to use the Australian ballot for the first time. This stipulation required that each person be given a secret ballot, which the election judge and clerk would endorse and stamp. ${ }^{62}$ While the clerks were supposed to be appointed no more than twenty days and no fewer than ten days prior to the election, they had been appointed twenty-six days prior to the election. ${ }^{63}$ Though Brown and the Republicans had not defeated segregation, they had meticulously threaded the electoral regulations into the legislation. This act of subversion also provided cause for an aggrieved party, including Wilson, to seek remedy and to challenge the system of segregated schools. It also allowed Brown to shift from his role as legislator to that of attorney general and plead the territorial case in court on behalf of Wilson's children.

Rather than a blatantly racist proceeding, the first territorial legislature and its aftermath was in fact deeply divided on the subject of segregation in territorial schools. Many schools, including the one the Wilson children attended in Guthrie, were integrated. Many blacks in the territory - adults and children — had attended integrated schools in Kansas, in Indian Territory, and at military installations. Legislators had come from states where schools were integrated. For them, Council Bill No. 2 and the elections that followed were a step back on the road to equal participation in education. But the battle was not over.

\section{Wilson v. Marion}

For the Wilsons, and attorneys Brown and Soward, there was every reason to be optimistic about the outcome of Wilson v. Marion. By 1890, African Americans had long been litigating school segregation in lower courts throughout the United States, though the issue had never reached the US Supreme Court, and few cases were used as precedent. Many cases were not reported at all. Nevertheless, the numbers indicate that African Americans frequently sought remedy for perceived educational inequality, citing "reasonably equal" language from the earliest case, Roberts $v$. Boston (1849), decided before the Civil War and thus also before passage of the Fourteenth Amendment. In Roberts v. Boston, Chief Justice Lemuel Shaw found segregation to be legitimate but specified that schools must be reasonably

\footnotetext{
${ }^{62}$ Brief for the Defendant filed by Brown and Soward, Marion v. Territory.

${ }^{63}$ Decision, Wilson, v. Marion. The decision references the Statutes of Oklahoma, Article 13, Section 4.
} 
equal. ${ }^{64}$ This language of equality would persist even as individual trial results-eighty-two between 1834 and 1903 found to date-varied widely, depending on state constitutions and laws. Still, the odds for the Wilson case were good; after 1880, black plaintiffs prevailed 75 percent of the time. Percentages were even higher where no state law dictated segregation, so Wilson had reason to expect a fair redress of grievances. ${ }^{65}$

Locally, when Belle Wilson attempted to enroll her daughters, the debate over whether Guthrie would segregate its schools had been ongoing, contentious, and publicized. Though the county vote "showed a large majority in favor of separate schools for the education of white and colored children," the election had enough irregularities to allow the Wilsons to challenge not only the equality of the facilities for black students but the legality of the election held to create the schools in the first place. ${ }^{66}$ On October 31, 1891, Attorney General Brown, representing the territory, filed a writ of mandamus in district court on behalf of Wilson, claiming that such a refusal to admit the girls "deprived [them] of the advantages and means and prohibited [them] from obtaining instruction and education in the Public School of said City of Guthrie." ${ }^{67}$ The writ prayed that the court command the school district to admit the girls to their former school. On February 23, 1892, the hearing was held to determine the validity of Wilson's complaint.

On May 23, 1892, Judge Green heard Territory ex rel. Wilson v. Marion et al., Board of School Trustees in the First District Court. Green was one of the federally appointed northern Republicans present in Oklahoma Territory; an Illinois native, he was appointed chief justice of the territorial supreme court by President Harrison. Because of his potential sympathy for the case, Brown and Soward tailored the territory's argument in two ways: they argued that the school provided for the Wilson children failed to meet the legislation's equal protection clause, and that the elections held in Logan County were invalid.Judge Green ultimately found that the schools "maintained for the education of colored children ... are equal in every respect to those maintained for the education of white children ... the colored pupils having exactly the same facilities for the acquiring of education enjoyed by the white children of the City" and that a tax was levied "sufficient to provide for the maintenance of said schools." 68 This part of Green's decision reveals a clear legal understanding that the separate

\footnotetext{
${ }^{64}$ Roberts v. Boston, 59 Mass. (5 Cush.) 198 (1850).

${ }^{65}$ Tignor Peterson, "Legal Aspects of Separation," 356-62.

${ }^{66}$ Brief of the Appellants, Marion v. Territory, 21.

${ }^{67}$ Writ of Mandamus, Wilson v. Marion.

${ }^{68}$ Edward B. Green, Decision, Wilson v. Marion in Brief of the Appellants, Marion
} v. Territory, 21. 
schools provided for African American students must be "equal"drawing both on the territorial legislation and also, though not cited, older case law regarding segregated schools. ${ }^{69}$

Instead of finding the separate schools unequal, Judge Green turned to the argument on the lesser complaint concerning the legality of the election. He found that the way in which the judges and clerks who presided over the county election were appointed did not meet the requirements of the territorial statute "and their failure to appoint within the time prescribed ... rendered the election void." He further wrote that because of this irregularity "no separate schools for the education of white and colored children could be established." 70 On this basis alone, Judge Green found for the territory and the Wilsons. His rationale is in keeping with a number of rulings in other courtrooms in the nation where judges deferred the constitutional question of separate educational systems in favor of ruling on more narrowly defined technicalities. $^{71}$

In response to Judge Green's ruling in the Wilson case, Guthrie's Republican-leaning newspaper, The Weekly Oklaboma State Capitol, questioned: "Illegal?: Was the Guthrie Separate Schools Election." The paper states, "This decision is one of great importance to the people and, if it stands, will prove a great relief to the country districts in Logan County as it will relieve them from the burden of supporting a double set of schools." ${ }^{2}$ The paper reveals that white support for separate schools was not universal. This district ruling and subsequent white reaction speak to the complexity of the roles whites would play in the battle to define the nature of the territory through its schools. White northern allies, as well as federal oversight of the territory, played a part in the Wilsons' success. The Wilsons refused to allow the narrowing of their daughters' educational opportunities, and their legal challenge would serve not only their daughters but the broader cause of equal educational access. This case would

${ }^{69}$ The most significant cases include: Roberts $v$. Boston (1850) and then later Bertonneau v. Board of Directors of City Schools (1878) and Board of Education v. Tinnon (1881). U.S. v. Buntin (1882) from Ohio shares with Wilson v. Marion the federal presence filing suit on behalf of an aggrieved person, though clearly it was highly unusual for a territory to file a constitutional suit against a school board. Tignor Peterson asserts that legislative language is the best indicator of successful educational segregation litigation. Tignor Peterson, "Legal Aspects of Separation," 373; See also Riegel, "The Persistent Career of Jim Crow," 28.

${ }^{70}$ Decision, Wilson v. Marion. Also from Brief for the Defendant, Marion v. Territory.

${ }^{71}$ Kousser, Dead End, "Before Plessy, before Brown"; and Tignor Peterson, "Legal Aspects," 373-74.

${ }^{72}$ Weekly Oklahoma State Capitol (Guthrie, OK), April 30, 1892, 6. 
fundamentally determine the course that the territory would take on its path to statehood.

The school district immediately appealed Judge Green's decision, which meant that African American students around the territory would continue to attend segregated schools. Instead of waiting for the matter to wind its way through the courts, African American activists took the battle to the classroom. Contemporary newspapers reported that "the negroes are not content to await a decision, but are trying to force their ways in the [white] schools." The paper states that "though they have been given all the facilities and accommodations equal to the white children, they are not satisfied and demand admission to the white schools." 73 The story goes on to describe that in Kingfisher, where schools had similarly been segregated:

Forty negro children, backed by a crowd of adults, entered a white school and took seats, and it was necessary to use force to remove them. As a result open violence is advocated by many. Negro preachers from the pulpit are advising their people to use force if necessary to get into the white schools, and an open warfare is likely to break out at any time. ${ }^{74}$

The "equality" of the schools for black students must be questioned if parents and students alike were demanding, both through civil disobedience and court order, a redress to the situation. An article in the same paper on October 22 described similar acts of civil disobedience in Oklahoma City, stating that "the colored people say that they are as good as white people and will not patronize the public schools unless allowed to send to the white schools." 75 African Americans within the territory clearly would not accept the terms of secondclass citizenry being exacted by denying them equal educational access. Though the school board's appeal to the territorial supreme court meant that the schools would remain segregated if Judge Green's decision was upheld, it also meant that schools would be mixed until the matter was to be voted on again in April 1894, as legislation dictated.

The appeal was heard in 1892 during the September term of the territorial supreme court, and a decision was handed down on January 27, 1893. Judge Green from the First District also served as chief justice, along with Justices John H. Burford and John G. Clark-all

73 "Race Troubles Likely, Mixed Schools Wanted by Negroes and Violence Feared," Weekly Oklahoma State Capitol (Guthrie, OK), Oct. 8, 1892, 7. Feared."

74 "Race Troubles Likely, Mixed Schools Wanted by Negroes and Violence

75 "Negroes Want to Attend White Schools," Weekly Oklahoma State Capitol (Guthrie, OK), Oct. 22, 1892, 7. 
Harrison appointees - Burford would later be appointed chief justice. Justices Burford and Clark both disagreed with Judge Green. Burford delivered the court's two-to-one decision in favor of the Logan County school board, writing:

\begin{abstract}
Mere technical irregularities and omissions [in the appointment of judges and clerks] should not be permitted to defeat the popular will, in any case when there has been an attempt to conform to the requirements of the statute and no injury has resulted to any one. ... It will not be contended that the irregularity in the appointment of the judges, in any manner or to any degree prevented a free and fair exercise of the elective franchise in this case. ${ }^{76}$
\end{abstract}

Chief Justice Green dissented, maintaining his lower court decision: "Whether it is better to maintain a system of separate schools for white and colored children, or to maintain a system of mixed schools, are questions with which the courts have nothing to do, and should be left entirely to the legislative branch of the government." But he continued, citing the territorial statute, that "Any failure to comply with any and all the provisions of the act, shall render such act of establishing separate schools void [emphasis added]." Though Green was overruled, he remained adamant in his dissent, concluding that "it does not lie with the courts to say that the will of the legislature shall not be respected, and that separate schools shall be established whether the provisions of the act have been complied with or not." ${ }^{\prime 7}$ His respect for the will of the legislature (at that time held by a narrow Republican majority) points to his Republican roots and to the efficacy of the legal challenge the territory mounted on behalf of the Wilsons that, in the appeal, focused exclusively on voting irregularities.

The territory lost. The Wilsons lost. And Brown lost- the following year, his appointment as attorney general went to someone else. The bank foreclosed on his and his wife's properties, and he soon left the territory for Colorado, his legacy overshadowed by subsequent legislation. In 1893, Congress provided for two additional seats on the territorial supreme court to be filled by the new Democratic president, Grover Cleveland. The same year, Cleveland also replaced Justice Green, acquiring a majority of appointments on the high court. ${ }^{78}$

The Wilsons found a more creative way to get the education they demanded for their children. When the area just north of the

\footnotetext{
${ }^{76}$ Marion v. Territory, at 222.

${ }^{77}$ Dissenting opinion by Chief Justice E. B. Green, Marion v. Territory, at 223, 225.

${ }^{78}$ Thomas Doyle, "The Supreme Court of the Territory of Oklahoma," Chronicles of Oklahoma 13, no. 2 (June 1935), 215.
} 
Unassigned Lands, the Cherokee Strip, opened by land run in 1893, Wilson acquired a prime piece of property on the recently created Grand Boulevard in Ponca City. Following his long proven formula for economic success, he opened a new barbershop that catered to the community's civic elites. Meanwhile, Belle, Eva, Janetta, and now son Alfred moved back across the Kansas border to Arkansas City, where the children received an integrated education. When Eva reached the age of 19 , she was still attending school, as were her younger siblings. Arkansas City was just a few miles from Winfield and a short thirtyminute train ride from Ponca City. Though they maintained separate residences (both owned free and clear), no doubt Wilson took advantage of the short commute. In order for the family to participate in the promise of the territory, economic opportunity and civic participation, they would have to literally straddle the boundary between the two.

Justice Green, writing later about his time in Oklahoma Territory, described the legal atmosphere as "sui generis"—of its own kind-highlighting the less precedent-dependent, more pragmatic, and ultimately more fluid nature of law in the West. The loss for the territory and the Wilsons points instead to the durability of a reemerging racial hierarchy that came despite the flexibility of the law and the conditions that existed in the territory for African Americans, conditions that included economic opportunity for African Americans and the organizational grassroots movements that came with those communities. The loss came in spite of the federal oversight and help from white allies. The loss for the Wilsons reveals the endurance of a racial order more rigidly drawn than many might have hoped. Yet that fight continued.

Though the Wilsons were the first to demand equal access for their children in the territory, they were not the last. Many other cases during Oklahoma's territorial years show that African Americans were not content to accept segregation in the schools but had narrowed their legal focus on demanding equal funding-a tactic the NAACP later adopted in its legal battle to end segregation. ${ }^{79}$ Throughout the territorial years, a wide disparity existed in the funding of white and black schools. Oklahoma's low tax base created conditions under which the funding of one set of schools would be

${ }^{79}$ Taylor views this pivot to funding challenges in Texas and Oklahoma particularly as a reflection of the entrenched "segregationist ideology." His view that African American leaders were "reduced to arguing for equitable appropriations" in Oklahoma and Texas seems to undercut the pragmatic legal strategy that demanded that separate schools must be equal schools. Taylor, In Search of the Racial Frontier, 219. 
difficult, let alone two. ${ }^{80}$ Numerous cases were filed during the territorial years, including Porter v. Commissioners of Kingfisher County (1898) - a case that also went to the territorial supreme court. The arguments in Porter were notable in that they invoked both the Fourteenth Amendment's equal protection clause, the Fifteenth Amendment's prohibition on abridging voting rights, as well as the territory's Organic Act, which required that, "There shall be no denial of the elective franchise or of holding office, to a citizen, on account of race, color, or previous condition of servitude." 81 That argument proved successful in striking down an 1897 school segregation law, one that mandated blacks could vote only for their separate school board and whites could only vote for theirs. ${ }^{82}$ The Porter decision forced the territory to revert to the county-option segregation law passed in 1890. Most importantly, it established legal precedent that would come back later in similar challenges during the state's legal history.

Cases followed that challenged the funding disparity, including School District No. 76 v. Capitol National Bank $(1898)^{83}$ and The Board of Education of Kingfisher County v. Kingfisher County Commissioners (1904), in which the territorial supreme court barred the school district from selling for a profit the school building for black students. ${ }^{84}$ Despite the legal shift toward attacking unequal funding, other cases challenged, as Wilson $v$. Marion did, educational access for black students. In Dewberry v. Crooks, Fawley, and Lewis (1903), and later Harrison v. Barden, Clingan, and Gordon (1903), parents sued their children's school districts for damages for failure to provide them a separate school. ${ }^{85}$ These are among the eight known cases decided during Oklahoma's territorial years.

The 1890s saw a flourishing of segregation cases across the country, and Oklahoma was on the forefront of this legal battleground. ${ }^{86}$

${ }^{80}$ Franklin, Journey toward Hope, 61.

${ }^{81}$ Oklahoma Organic Act, 26 Stat. $81 \$ 5$ (1890).

${ }^{82}$ Hatcher, "The Development of Legal Controls," 91; and Porter v. Commissioners of Kingfisher County, 6 Okla. 550 (1898). See also Davenport v. Cloverport, 72 Fed. 689 (D. Ky. 1896).

${ }^{83}$ School District No. 76 et al. v. Capitol National Bank, 7 Okla. 45, 54 P. 309 (1898).

${ }^{84}$ Board of Education of the City of Kingfisher v. Board of County Commissioners of Kingfisher County, 14 Okla. 322, 78 P. 455 (1904).

${ }^{85}$ Dewberry v. Crocks, Fawley and Lewis, District Court of the Seventh Judicial District, Comanche County, (1903); and Harrison v. Birden, Clingan, and Gordon, District Court of the Seventh Judicial District, Comanche County, (1903). Manuscripts of both cases are available in the archives of the Museum of the Great Plains in Lawton, OK.

${ }^{86}$ Camille Walsh, "Separate and Double Taxation: School Finance and Racial Inequality in the Early Twentieth Century" (presentation, History of Education Society 57th Annual Meeting, Little Rock, AR, Nov. 2-5, 2017). 
The many legal challenges to segregation in Oklahoma Territory were contemporaneous with the US Supreme Court's enshrining of the very language "separate but equal," first and most famously in Plessy $v$ Ferguson. Then, in 1899, Cumming v. Richmond County Board of Education came before the high court, the first case to test the separate but equal doctrine in schools. In this case, black children in Richmond, Georgia, were denied construction of a high school though white children had two. In its astonishing decision, the court ruled that separate schools, in this case clearly not equal, did not violate the Fourteenth Amendment. Nevertheless, in Oklahoma Territory, despite these crushing national defeats, African American activists barely broke stride. In an analysis of reported cases during the territorial years, 1889-1907, black activists and their reform-minded white allies brought more cases than anywhere else in the country, with only Kansas, Kentucky, and North Carolina coming close to the number of cases. ${ }^{87}$ Clearly, the territory's African American population, with more federal protections and more access to capital and educational opportunities, was determined to hold on to those hard-earned rights. They did so in the territorial courtroom.

Wilson $v$ Marion has not been a visible case historically. It provided no legal precedent. Like much of black legal history, it was relegated to invisibility. Legal scholarship has largely focused on the twentiethcentury constitutional challenges that directly culminated in the "win": Brown v. Board of Education. This work reveals a deeper foundation for these later battles. Wilson v. Marion became the cornerstone of the black legal activism culture that would follow in Oklahoma Territory. Equal protection under the law would not mean equality in schools for many years, but it did mean equal access to seek redress. Wilson and the legal activism that followed should be seen as one continuous legal thread that runs through the many local confrontations, district courtrooms, state supreme court cases, and the US Supreme Court. Oklahoma Territory and, after 1907, the state of Oklahoma, provided fertile legal ground. In the 1940s, when the NAACP began its formal assault on the separate but equal doctrine in education, lawyers, including Thurgood Marshall, found a willing Ada Lois Sipuel Fisher-who graduated as valedictorian from what was once the only black high school in the southern half of Oklahoma Territory-to challenge state segregation law in its only law school. In Sipuel v. Board of Regents of University of Oklaboma (1948) and then McLaurin v. Oklahoma State Regents (1950) the US Supreme Court struck down segregation in law schools and in college graduate schools. ${ }^{88}$ The roots of these cases were territorial.

${ }^{87}$ Tignor Peterson, "Legal Aspects of Separation," 356-62.

${ }^{88}$ Sipuel v. Board of Regents of Univ. of Okla., 332 U.S. 631 (1948); and McLaurin v. Oklahoma State Regents, 339 U.S. 637 (1950). 
Ralph Ellison, writing about his upbringing in Oklahoma in the days of early statehood, said, "For out there our people fought back ... we seldom won more than moral victories, but we fought backas can be seen from the many civil rights victories that were initiated there." 89 Ellison paints an accurate picture of the early legal battle against segregation in the territorial days and the battles that would come later in the twentieth century. Oklahoma Territory was a place like no other-a place enshrined in African American folklore as offering what the rest of the country could not, a place where African Americans had so many conditions in their favor that they resisted any curtailment of those opportunities. These pioneers used the law as one of their tools, and the law responded. More significantly, the law was seen as responsive by a striving African American population. In a legal era that brought Plessy and Cumming, this black activism in the unpredictable space of the territorial courtroom is noteworthy.

Despite the compelling narrative strands that drew John Wilson and others to Oklahoma Territory, a competing story that others sought to carve into the space was one of white supremacy. Many whites felt the reports that the new territory featured integrated schools would provide too much incentive for black migration and would create a very real "black Eden," as African American boosters portrayed. ${ }^{90}$ These competing forces plainly saw that schools must not increase the advantage of equal opportunity. Though the land itself could not be withheld on the basis of race, education could. Wilson $v$. Marion provides a more complex interpretation of African American resistance to this attempt to curtail the right to education as a fundamental component to territorial citizenship. The case also informs us about the vulnerability of federal oversight, both judicial and executive, as local control gained power. Finally, the story of Wilson $v$. Marion helps challenge the dominant narrative that Jim Crow school segregation in Oklahoma was inevitable-that stilldominant narrative seeks to erase the complexity of the space and the hard-fought battles that shaped it-a history that is complicit with racial hierarchy. This new story resurrects a more complex story of resistance and persistence, one that expands our understanding of the opportunities of the racial frontier and the forces of "civilization" that ultimately curtailed them.

\footnotetext{
${ }^{89}$ Ellison, Going to the Territory, 208.

${ }^{90}$ Wicket, Contested Territory, 85.
} 